\title{
BERMAIN SEBAGAI INTERVENSI UNTUK MENINGKATKAN KOMPETENSI SOSIAL ANAK
}

\author{
Hendi Suhendraya Muchtar' ${ }^{1}$, Alifah Indalika Mulyadi Razak ${ }^{2}$ \\ Universitas Islam Nusantara \\ E-Mail: hendipnf@yahoo.com ${ }^{1}$, indarazak@yahoo.com²
}

\begin{abstract}
ABSTRAK
This study aims to examine the play stimulation model to improve children's social competence. The study involved 100 children in the kindergarten age group. The types of play in this study are divided into four games patterns, namely the solitary independent play, parallel play, associative play, and cooperative play. Each play pattern is tested with four dimensions of social competence, which consist of self-concept, ability to manage emotions, prosocial and social-academic behavior. The results of this study indicate that more than 50\% of the four dimensions of social competence are effectively stimulated through cooperative play patterns. Cooperative play patterns are effective for stimulating self-concept dimensions (10 of 15 behaviors), emotional management abilities (9 of 18 behaviors), social academics ( 7 of 15 behaviors), and prosocial behavior (17 of 23 behaviors). The pattern of associative play effectively stimulates the dimensions of self-concept ( 3 of 15 behaviors), emotional management skills ( 7 of 18 behaviors), prosocial behavior ( 4 of 23 behaviors), and social academics ( 3 of 15 behaviors). The effective parallel play and solitary independent play patterns of each play only stimulate 1 social competence behavior.
\end{abstract}

Keywords: cooperative play, associative play, parralel play, solitary independent play, social Competencies

Penelitian ini bertujuan untuk menguji model stimulasi permainan untuk meningkatkan kompetensi sosial anak. Penelitian ini melibatkan 100 anak pada kelompok usia taman kanak-kanak. Jenis permainan pada penelitian ini terbagi ke dalam empat pola permainan, yaitu solitary independent play, parralel play, associative play, dan cooperative play. Setiap pola permainan diujikan dengan empat dimensi kompetensi sosial, yang terdiri dari konsep diri, kemampuan mengelola emosi, perilaku prososial dan sosial-akademik. Hasil penelitian ini menunjukkan bahwa lebih dari 50\% empat dimensi kompetensi sosial efektif distimulasi melalui pola permainan cooperative play. Pola permainan cooperative play efektif untuk menstimulasi dimensi konsep diri (10 dari 15 perilaku), kemampan mengelola emosi ( 9 dari 18 perilaku), sosial akademik ( 7 dari 15 perilaku), dan perilaku prososial (17 dari 23 perilaku). Pola permainan associative play efektif menstimulasi dimensi konsep diri ( 3 dari 15 perilaku), kemampuan mengelola emosi (7dari 18 perilaku), perilaku prososial (4 dari 23 perilaku), dan sosial akademik ( 3 dari 15 perilaku). Pola permainan parralel play dan solitary independent play masing-masing efektif hanya menstimulasi 1 perilaku kompetensi social.

Kata Kunci: Anak Usia Dini, Bermain Kooperatif, Bermain Asosiatif, Bermain paralel, Bermain soliter, Kompetensi sosial 


\section{PENDAHULUAN}

Permainan merupakan salah satu kegiatan yang sangat penting dalam kehidupan. Melalui permainan, anak-anak dapat belajar untuk aktif, kreatif, dan berinovasi untuk menciptakan hal-hal baru (Berk, 2008). Bahkan (Vygotsky dalam Berns, 2010) mengatakan bahwa permainan merupakan kegiatan yang dapat menstimulasi anak-anak untuk mengenal aturan masyarakat, mengenal moral, mengenal bagaimana mengatasi berbagai macam masalah yang terjadi dalam kehidupan. Hal ini selaras dengan kompetensi sosial yang menggambarkan kemampuan anak untuk mengendalikan emosi diri dan menjalin hubungan baik dengan orang lain (Baron \& Byrne, 1997).

Penelitian ini bertujuan untuk menguji bentuk-bentuk permainan yang sesuai dengan kompetensi sosial anak (lihat gambar 1) berdasarkan pola permainan sosial dari Mildred Parten yang terdiri dari unoccupied behavior, onlooker behavior, solitary independent play, parralel play, assosiative play dan cooperative play Parten dalam (Henniger, 2013) meneliti secara khusus bagian solitary independent play, parralel play, assosiative play, dan cooperative play yang seringkali dijumpai pada anak-anak usia prasekolah (Kail, 2012). Tahapan permainan solitary independet play biasanya dialami oleh anak yang berusia diatas 3 tahun, yakni suatu tahapan permainan dimana anak menonton orang lain bermain, tetapi berbicara kepada anak lain dan menanyakan perilaku permainan temannya (Morrison, 2012).

Parralel play umumnya dialami oleh anak-anak sebagai upaya adaptasi anak terhadap lingkungan barunya, biasanya parralel play ini dialami oleh anak yang baru pertama kali bergabung dalam lingkungan sekolah (Bronfenbrenner, 1993). Dalam parralel play, anak-anak tidak saling berinteraksi tetapi bermain bersama dalam satu ruangan. Sementara assosiative play merupakan pola permainan dengan melibatkan sedikit interaksi seperti berbicara atau saling mempengaruhi permainan satu sama lain (Papalia \& Feldman, 2012). Cooperative play merupakan pola permainan yang melibatkan tingkat sosialisasi paling tinggi, dimana anak-anak belajar untuk bekerjasama dalam kegiatan permainan (Santrock, 2011).

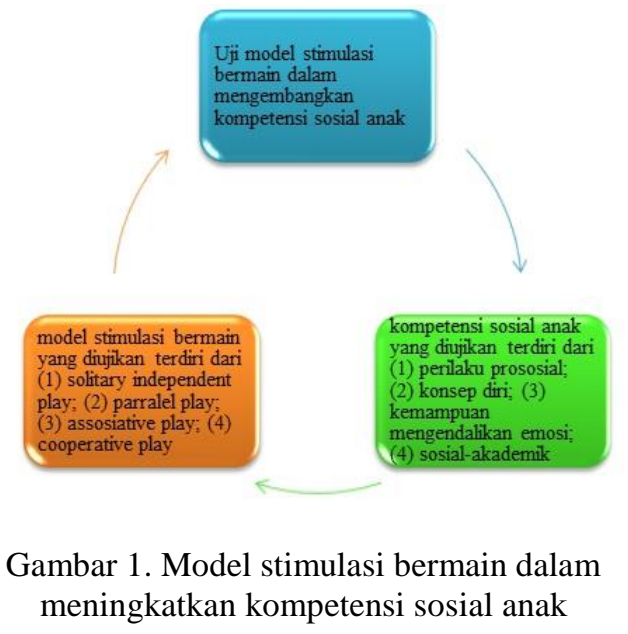




\section{KAJIAN TEORITIK}

Pola-pola permainan tersebut kemudian dihubungkan pada dimensi kompetensi sosial berdasarkan hasil penelitian sebelumnya (Mulyanto, A., Muchtar, H.S., Hoerudin, \& Razak, 2017), yang terbagi ke dalam empat dimensi kompetensi sosial, diantaranya : konsep diri, kemampuan mengendalikan emosi, perilaku prososial, dan sosial akademik (Mulyanto, A., Muchtar, H.S. et al., 2017). Konsep diri berkenaan dengan kemampuan anak untuk mengenal dan merawat dirinya. Kemampuan mengendalikan emosi merupakan kompetensi yang dimiliki anak untuk mengenal dan mengendalikan diri untuk menghadapi orang lain. Perilaku prososial merupakan kemampuan anak untuk menolong, berbagi, bekerjasama, serta menyelesaikan konflik dalam hubungan sosialiasi. Sementara sosial-akademik merupakan kemampuan anak untuk menguasai aturan-aturan sekolah sebagai tahap pertama kehidupan bermasyarakat (Mulyanto, A., Muchtar, H.S. et al., 2017). Bermain merupakan salah satu kegiatan penting dalam pengembangan diri anak. Bermain dianalogikan sebagai pusat kegiatan, pusat berpikir, dan pusat imajinasi anak (Vygotsky dalam Morrison, 2012). Kegiatan bermain dapat meningkatkan kompetensi sosial, yang diartikan sebagai sejumlah kemampuan yang berkenaan dengan pengenalan emosi, kemampuan beradaptasi, serta kemampuan mengelola diri (Xinyin, C. Dan, Li, Li, \& Liu., 2000).

Fokus penelitian ini adalah pada kompetensi sosial yang terdiri dari sub kompetensi (1) konsep diri; (2) kemampuan mengelola emosi; (3) perilaku prososial; (4) kemampuan sosial-akademik (Mulyanto, et.al 2017). Konsep diri (the self-concept) diartikan sebagai sesuatu yang unik (Betti dalam Santrock, 2011). Dalam deskripsinya Betti memaparkan bahwa konsep diri menggambarkan harga diri dan identitas diri. Hasil penelitian Harter (2006, dalam Santrock, 2011) menunjukkan bahwa ketika anak-anak memiliki harga diri yang rendah, dapat mempengaruhi prestasi belajarnya, sementara kemampuan mengelola emosi (emotional well-being), yakni kemampuan anak untuk mengidentifikasi emosi, mengelola, dan mengendalikannya (Spivak \& Howes, 2011). Perilaku prososial merupakan kemampuan anak untuk berperilaku seperti menolong, membantu (Ruffo, 2003), bekerjasama dengan teman (Iannotti, 1986), mampu bermain bersama teman, serta mampu menyelesaikan masalah (Henson \& Eller, 1999), sementara sosial-akademik (Social Academic) merupakan kemampuan anak untuk mengikuti aturan di masyarakat, dalam hal ini anak lingkungan mikrosistem (Bronfenbrenner, 1993) adalah sekolah, yang ditandai dengan 
kemampuan menyelsaikan konflik dengan teman, mengikuti rutinitas sekolah serta ketuntasan belajar.

\section{METODOLOGI PENELITIAN}

Penelitian ini melibatkan 100 orang anak usia 4-6 tahun di Taman Kanak-kanak provinsi Jawa Barat, dengan menyebarkan 68 item kompetensi sosial yang terbagi ke dalam empat dimensi kompetensi yang disesuaikan dengan stimulasi permainan solitary indepenent play, parralel play, associative play, dan cooperative play. Sampel penelitian ditentukan berdasarkan teknik purposive sampling. Penelitian ini menguji instrumen stimulasi permainan yang sesuai dengan kompetensi sosial anak, sehingga akan muncul model stimulasi permainan yang sesuai dengan empat dimensi kompetensi sosial anak. Metode penelitian mix-method model (Kumar, 2011), digunakan untuk menguji instrumen permainan yang telah disusun oleh peneliti. Terdapat 10 langkah penelitian ini, namun baru 5 langkah yang dilalui peneliti untuk menciptakan model stimulasi permainan kompetensi sosial, diantaranya:

1. Tahapan Research and information collecting, yakni tahapan penyusunan teori dasar permainan yang melibatkan pola permainan kognitif Sara Smilansky (Smilansky, 1968 dalam Essa, 2003), pola permainan sosial Mildred B.
Parten (Parten, 1932 dalam Essa, 2003), pola permainan Kathleen Stassen Berger yang fokus pada media permainanya (Berger, 1983 dalam Tedjasaputra, 2001). Konstruk penelitian tersebut disusun untuk menghasilkan model stimulasi permainan untuk kompetensi sosial anak.

2. Tahapan planning yakni penyusunan jadwal penelitian yang meliputi teknis penelitian, menjalin komunikasi dengan subjek penelitian, serta sampai pada tahap uji coba terbatas dan uji coba luas.

3. Tahapan development of the preminary form of product, mengembangkan produk berupa pedoman umum untuk guru yakni pedoman mengobservasi kompetensi sosial anak

4. Tahapan preliminary filed testing, yakni uji coba terbatas yang melibatkan 100 orang anak Taman Kanak-kanak di TK Kota Cimahi untuk diobservasi kegiatan permainannya yang dikaitkan dengan kompetensi sosial. Hasil reliabilitas menunjukkan bahwa $(\mathrm{r}=0.966>\mathrm{r}$ tabel $=$ 0.7), artinya instrumen perangkat stimulasi permainan menunjukkan stabilitas yang baik dalam penggunaannya, meskipun diterapkan pada subjek yang berbeda. 
Bermain Sebagai Intervensi......

Hendi \& Alifah

Sementara uji validitas perangkat stimulasi, dari 68 item indikator dinyatakan 57 item valid, artinya lebih dari 80 $\%$ perangkat stimulasi permainan ini dapat digunakan untuk meningkatkan kompetensi sosial anak.

5. Tahapan main product revision, yakni memperbaiki model instrumen stimulasi permainan baik dari segi penerapan uji, maupun item-item yang tidak valid. Model isntrumen stimulasi permainan tersebut diujikan bersamaan dengan empat dimensi kompetensi sosial (Mulyanto, A., Muchtar, H.S. et al., 2017), diantaranya konsep diri (15 item indikator), kemampuan mengelola emosi (18 item indikator), perilaku prososial (23 item indikator) dan sosial akademik (12 item indikator).

Dalam penelitian ini, peneliti bertindak sebagai instrumen utama untuk menjaring data dan informasi dengan menggunakan teknik observasi, studi dokumentasi, dan wawancara. Khusus untuk mengumpulkan data dalam pelaksanaan penelitian pengembangan model bentuk deteksi dan stimulasi yang selama ini dilakukan oleh guru di Taman Kanakkanak dalam pengembangan kompetensi sosial anak usia dini di Jawa Barat digunakan observasi partisipan dan wawancara tidak terstruktur. Observasi partisipan dilaksanakan ketika studi pendahuluan dan selama proses uji coba pengembangan model. Aspekaspek diobservasi adalah frekuensi kemunculan perilaku menggambarkan deskripsi perilaku kompetensi sosial anak usia dini yang terjadi di TK di lingkungan provinsi Jawa Barat.

Analisis data dilakukan sepanjang penelitian dilaksanakan dan mengacu pada model analisis data kualitatif menurut pendapat Kumar (2011) yang mengemukakan langkah analisis data yang terdiri atas tiga alur, yakni: reduksi data, penyajian data, dan penarikan kesimpulan, melalui langkah-langkah sebagai berikut:

1. Reduksi Data: data yang diperoleh di lapangan ditulis/ditik dalam bentuk uraian atau laporan terperinci. Laporan yang disusun kemudian direduksi, dirangkum, dipilih hal-hal pokok, difokuskan pada hal-hal yang penting dan dicarikan temanya.

2. Display Data: data yang telah diperoleh diklasifikasikan menurut pokok permasalahan dan dibuat dalam bentuk matriks sehingga memudahkan peneliti untuk melihat hubungan suatu data dengan data yang lainnya.

3. Mengambil Kesimpulan dan Verifikasi: peneliti membuat kesimpulan berdasarkan data yang telah diproses melalui reduksi dan display data. 
Proses mereduksi data merupakan langkah analisis melalui proses pemilihan, memfokuskan perhatian pada penyederhanaan, pengabstrakan dan transformasi data mentah yang muncul dari catatancatatan tertulis di lapangan. Dalam penelitian ini, proses reduksi data dilakukan sejak peneliti memasuki wilayah penelitian sampai pada akhir penelitian. Demikian pula halnya pada saat pengumpulan data berlangsung. Penulis secara berkesinambungan melakukan reduksi data melalui kegiatan: membuat ringkasan, membuat kode, menelusuri kode, dan lain-lain. Proses reduksi merupakan langkah analisis dalam memfokuskan, menggolongkan, mengarahkan, membuang yang tidak perlu dan mengorganisasikan data sehingga memudahkan dalam menarik kesimpulan. Proses reduksi juga dalam rangka memilih dan memilah data pokok dan data pelengkap yang sesuai atau bahkan sebaliknya bertentangan dengan fokus penelitian.

Data yang telah dipilah, kemudian disajikan dalam deskripsi penyajian data yang dibentuk dalam format teks naratif, tabel, matrik, bagan, dan lain-lain. Data-data tersebut diselaraskan dengan melihat keterkaitan antara data penelitian yang terkumpul dengan penarikan kesimpulan. Dengan demikian, proses analisis data dalam penelitian ini dapat dilakukan berulang kali, kontinyu, dan berkesinambungan .

\section{HASIL DAN PEMBAHASAN}

Penelitian ini bertujuan untuk meningkatkan kualitas model stimulasi permainan yang sesuai dengan kompetensi sosial anak. Terdiri dari 68 item indikator kompetensi sosial yang diujikan dengan stimulasi pola permainan sosial yakni solitary independent play, onlooker behavior, associative play, dan cooperative play. Hasil uji validitas menunjukkan bahwa dimensi kompetensi sosial konsep diri (10 indikator) dapat distimulasi menggunakan permainan cooperative play seperti pada item nomor 11 yakni anak mampu bergiliran $(r=0.840>r$ tabel $=0,632)$ dan juga pada item nomor 23 yakni anak mampu dipimpin temannya $(r=0.737>r$ tabel $=0.632$ ) menunjukkan bahwa item-item ini dapat distimulasi melalui permainan kerjasama. Artinya interaksi permainan yang tinggi, dapat menstimulasi kemampuan anak untuk bergiliran dan mampu dipimpin temannya.

Dimensi kompetensi sosial perilaku prososial (Iannotti, 1986) yang terdiri dari 23 indikator kemudian diuji untuk distimulasi menggunakan model permainan cooperative play, hasilnya menunjukkan sebanyak 17 indikator perilaku prososial diantaranya pada item nomor 1 yakni anak mampu bermain bersama teman $(r=0.853>r$ 
Bermain Sebagai Intervensi......

Hendi \& Alifah

tabel $=0.632$ ), nomor 6 yakni anak mampu berperilaku baik dengan temannya $(\mathrm{r}=0.853>\mathrm{r}$ tabel $=$ 0.632 ), perilaku nomor 14 yakni anak menyeleasikan konflik dengan bantuan orang dewasa $(r=0853>r$ tabel $=0.632$ ) merupakan indikator yang dinyatakan valid untuk distimulasi menggunakan permainan cooperative play. Sebagai contoh anak-anak yang enggan bermain bersama teman, sangat sesuai untuk dilibatkan dalam permainan yang melibatkan sosialisasi tinggi sehingga anak tersebut dapat mengenal temannya, mengatasi konflik permainan serta dapat mengasah kemampuan adaptasinya untuk kemudian muncul perilaku prososialnya seperti kemampuan membantu, berbagi, bekerjasama dan menyelesaikan konflik seperti pada indikator nomor $19 \quad(\mathrm{r}=0.666>\mathrm{r}$ tabel $=0.632$ ) yakni anak mampu memiliki inisiatif menciptakan suatu permainan atau kegiatan menunjukkan bahwa stimulasi permainan cooperative play dapat meningkatkan kemampuan imajinasi anak, mengidentifikasi temannya dalam memerlukan bantuan dan melibatkan orang dewasa untuk menyelesaikan masalah.

Dimensi

kemampuan mengelola emosi yang terdiri dari 18 item indikator, 9 perilaku diantaranya efektif distimulasi melalui cooperative play, diantaranya perilaku nomor 52 anak mampu mengenal ekspresi wajah sedih $(\mathrm{r}=$ $0.666>r$ tabel $=0.632$ ) Cooperative play dapat digambarkan sebagai permainan yang melibatkan kemampuan anak untuk dapat menikmati permainan bersama teman, sehingga didalamnya anakanak dilatih untuk menurunkan ego nya agar permainan dapat berjalan sesuai aturan (Henniger, 2013). Berbeda dengan associative play, dari 18 item indikator hanya 7 perilaku yang teruji efektif distimulasi menggunakan permainan asosiasi yakni lebih banyak melibatkan kemampuan imajinasi anak yang ditunjukkan pada perilaku nomor 53 yakni anak mampu mengenal ekspresi wajah marah $(r=0.665>r$ tabel $=0.632$ ) dan perilaku nomor 57 yakni anak mampu membuat label/julukan/panggilan tertentu kepada temannya $(r=0.665>\mathrm{r}$ tabel $=0.632$ ). Kedua perilaku tersebut lebih efektif distimulasi melalui permainan asosiasi, artinya anakanak membayangkan peristiwa yang dapat meningkatkan kemampuannya dalam mengenal ekspresi wajah marah dan membuat julukan kepada teman sebagai indikator dalam kemampuan imajinasinya (Papalia \& Feldman, 2012). Sementara pada pola permaian parralel play, dimana anakanak seolah-olah bermain bersama padahal sebenarnya bermain individu. Dilihat dari pola permainannya, solitary independent play, umumnya dialami oleh anakanak usia prasekolah, sementara anak-anak usia taman kanak-kanak 
umumnya telah meninggalkan tahapan permainan solitary independent play dan juga hanya sedikit yang berada pada tahapan permainan parralel play (Pang, 2010). Hasilnya menunjukkan bahwa kedua model permainan ini tidak terbukti efektif untuk menstimulasi kompetensi sosial anak.

Dimensi sosial-akademik yang terdiri dari 12 item indikator, 7 perilaku diantaranya efektif distimulasi melalui stimulasi cooperative play, yakni perilaku menuntaskan tugas-tugas belajar yang ditunjukkan pada perilaku nomor 26 yakni indikator perilaku anak mampu menyelesaikan tugas sampai tuntas $(\mathrm{r}=0.666>\mathrm{r}$ tabel $=$ 0.632), kemudian perilaku nomor 29 yakni indikator anak mampu bercerita kepada orang lain $(r=0.666>r$ tabel $=0.632$ ). Perilaku menaati aturan serta menuntaskan tugas belajar, umumnya dapat distimulasi menggunakan permainan kerjasama, karena anak-anak belajar melalui teman-temannya meniru temannya mengerjakan tugas. Sehingga sangat dimungkinkan bahwa stimulasi permainan kerjasama sangat efektif untuk meningkatkan kemampuan anak menuntaskan tugas belajar (Warren, Rogers-Warren, \& Baer, 1976).

\section{KESIMPULAN, IMPLIKASI DAN SARAN}

Model perangkat stimulasi permainan untuk meningkatkan kompetensi sosial anak, menunjukkan bahwa pola permainan cooperative play merupakan pola permainan yang paling efektif untuk menstimulasi dimensi kompetensi konsep diri (10 dari 15 perilaku), kemampan mengelola emosi ( 9 dari 18 perilaku), sosial akademik (7 dari 15 perilaku), dan perilaku prososial (17 dari 23 perilaku). Ditinjau dari pola permainannya, cooperative play memungkinkan anak-anak untuk mengenal aturan permainan, meningkatkan kemampuan berpikir melalui strategi permainan, menurunkan egoisme karena seluruh anak harus menaati peraturan permainan agar dapat berjalan, serta mampu mengenal kebutuhan temannya satu sama lain.

Sementara pola permainan associative play yang merupakan pola permainan mengasah imajinasi anak dapat efektif menstimulasi perilaku-perilaku kompetensi sosial yang tidak terlalu banyak melibatkan hubungan sosialisasi seperti tampak bahwa pada dimensi kompetensi konsep diri (3 dari 15 perilaku), kemampuan mengelola emosi (7 dari 18 perilaku), perilaku prososial (4 dari 23 perilaku), dan sosial akademik (3 dari 15 perilaku). Permainan asosiasi atau permainan imajinasi umumnya menstimulasi perilakuperilaku yang tidak mungkin muncul melalui permainan kerjasama. Pola permainan selanjutnya adalah parralel play, yakni permainan yang melibatkan anak-anak dalam satu 
Bermain Sebagai Intervensi......

Hendi \& Alifah

waktu dan satu ruangan, tetapi hampir tidak ada interaksi di dalamnya, sehingga anak masing-masing bermain sendiri-sendiri. Parralel play sebenarnya sudah sangat jarang dimiliki oleh anak usia taman kanakkanak, terbukti pada keempat dimensi, masing-masing hanya 1 perilaku yang dapat efektif distimulasi melalui parralel play. Begitu juga dengan solitary independent play yang biasanya dialami oleh anak usia prasekolah (23 tahun), dan terbukti bahwa masingmasing hanya 1 perilaku yang efektif distimulasi melalui solitary independent play.

\section{DAFTAR PUSTAKA}

Baron, R. A., \& Byrne, D. (1997). Social Psychology. Massachusetts: Allyn and Bacon.

Berk, L. E. (2008). Exploring Lifespan Development. Boston: Pearson Education, Inc.

Berns, R. M. (2010). Child, family, school, community: socialization and support. California: Wadsworth.

Bronfenbrenner, U. (1993). Ecological Models of Human Development. International Encyclopedia of Education, 3.

Essa, E. L. (2003). Introduction to Early Childhood Education (4th ed.). Canada: Thomson.

Henniger, M. L. (2013). Teaching Young Children: An Introduction. New Jersey: Pearson Education, Inc.
Henson, B. F. C., \& Eller, K. T. (1999). Educational Psychology For Effective Teaching. New York: Prentice Hall.

Iannotti, R. J. (1986). Naturalistic and structured assessments of prosocial behavior in preschool children: the influence of empathy and perspective taking. Developmental Psychology, 2, 46-55.

Kail, R. V. (2012). Children and Their Development (6th ed). New Jersey: Pearson Education, Inc.

Kumar, R. (2011). Research methodology: a step-by-step guide for beginners. London: SAGE Publication Ltd.

Morrison, G. S. (2012). Early childhood educatuion today (12th ed). New Jersey: Pearson Education Inc.

Mulyanto, A., Muchtar, H.S., Hoerudin, C. W., \& Razak, A. I. M. (2017). Kompetensi Sosial Anak: Deteksi dan Stimulasi. Bandung: Alifah Publishing.

Pang, Y. (2010). Lego games help young children with autism develop social skills. International Journal of Education, 2, 1-9.

Papalia, D. ., \& Feldman, R. D. (2012). Experience Human Development ((12th ed.)). New York: McGrawHill Companies, Inc.

Ruffo, M. J. C. (2003). Implications for influencing the sharing behavior of preschool children with special needs in the integrated classroom. University of Connecticut.

Santrock, J. W. (2011). Life-span development ((13th ed.)). New 
York: McGraw-Hill Companies, Inc.

Spivak, A. L., \& Howes, C. (2011). Social and relational factors in early educationand prosocial actions of children of diverse ethnocultural communities, (57) 1, 1-25.

Tedjasaputra, M. S. (2001). Bermain, Mainan dan Permainan untuk Pendidikan Anak Usia Dini. Jakarta: Grasindo.

Warren, S. F., Rogers-Warren, A., \& Baer, D. M. (1976). The role of offer rates in controlling sharing by young children. Journal of Applied Behavior Analysis, 9, 491-497.

Xinyin, C. Dan, L., Li, Z., Li, B., \& Liu., M. (2000). Sociable and Prosocial Dimensions of Social Competence in Chinese Children: Common and Unique Contributions to Social, Academic, and Psychological Adjustmen. Developmental Psychology, 36(3). 